\title{
Botany
}

\section{Evidence of starch accumulation in TBY-2 cells in the presence of auxin}

\begin{tabular}{|c|c|}
\hline Journal: & Botany \\
\hline Manuscript ID & cjb-2021-0085.R1 \\
\hline Manuscript Type: & Note \\
\hline $\begin{array}{r}\text { Date Submitted by the } \\
\text { Author: }\end{array}$ & 19-Jul-2021 \\
\hline Complete List of Authors: & $\begin{array}{l}\text { Ambrosini, Veronica; Université de Limoges Faculté des Sciences et } \\
\text { Techniques } \\
\text { Issawi, Mohammad; Université de Limoges Faculté des Sciences et } \\
\text { Techniques } \\
\text { Riou, Catherine; Université de Limoges Faculté des Sciences et } \\
\text { Techniques, PEIRENE EA7500 }\end{array}$ \\
\hline Keyword: & Amylopectin, amylose, starch, TBY-2 \\
\hline $\begin{array}{r}\text { Is the invited manuscript for } \\
\text { consideration in a Special } \\
\text { Issue? : }\end{array}$ & Not applicable (regular submission) \\
\hline
\end{tabular}

\section{SCHOLARONE Manuscripts}




\section{Note}

2

\section{Evidence of starch accumulation in TBY-2 cells in the presence of auxin}

4

$5 \quad$ Veronica Ambrosini*, Mohammad Issawi*, Catherine Riou ${ }^{\S}$

6

7 Université de Limoges, Laboratoire Peirene EA 7500, 123 avenue Albert Thomas, 87060 Limoges,

8 France.

9

$10 *$ Equal contribution

11 §Corresponding author: catherine.riou@unilim.fr; Tel: +33 555457474; Fax: +33 555457202 


\section{ABSTRACT}

14 Tobacco cell suspension (TBY-2) is known to produce starch when cultured in medium

15 supplemented with cytokinin or in hormone-free medium. Unexpectedly, TBY-2 cells,

16 continuously cultivated on auxin alone, were also able to accumulate starch at the beginning of

17 stationary growth phase with a yield of $9.22 \pm 0.68$ percent. This starch production was strongly

18 correlated with a 25 -fold increase in starch synthase activity. Moreover, this TBY-2 line was able

19 to produce an amylopectin-rich starch with a ratio amylopectin over amylose of 2.7 which also

20 linked to typical small granules (size around $1.4 \mu \mathrm{m}$ ). According to our preliminary results, this

21 plant cell suspension could produce a low-cost amylopectin rich starch needed in the food industry

22 for production of edible film or bioplastic without impacts from climate or season changes.

24 Keywords: amylopectin, amylose, starch, TBY-2 cells. 


\section{Introduction}

Over the last forty years, Tobacco Bright Yellow cell line (TBY-2) suspension, often compared to HeLa cells in mammalian research, was extensively used to gain insight into cell cycle regulation, program cell death or responses to biotic or abiotic stress (Kato et al. 1972; Nagata et al. 1992; Kobayashi and Hakumo 2003; de Pinto et al. 2013; Moscatiello et al. 2013; Riou et al. 2014; Takahashi et al. 2015; Srba et al. 2016). Indeed, compared to other plant cell suspensions, TBY-2 cells present some advantages that explain their great success. They mainly form small cell chains that are easy to label and count, are relatively homogenous in size and have a very high cell division rate (Nagata et al. 1992; Issawi et al. 2017).

TBY-2 cells are cultivated under darkness in a liquid synthetic medium derived from Murashige and Skoog and supplemented with auxin (2,4-D) (Murashige and Skoog, 1962). Surprisingly, TBY-2 cells do not need cytokinin to divide and grow although both growth factors auxin and cytokinin are normally required for the control of plant cell divisions (Miller et al. 1955; Coenen and Lomax 1997; Riou-Khamlichi et al. 1999; Jameson and Song 2016; Hurný and Benková 2017). Thus, it was thought that TBY-2 cells did not lose the ability to produce their own cytokinins. Furthermore, these cells have undifferentiated plastids called proplastids that are not able to produce and accumulate starch (Enami et al. 2011). Nevertheless, when transferred to medium that is missing auxin or supplemented with cytokinin, cells recovered the ability to produce starch into amyloplasts derived from proplastid differentiation (Sakai et al. 1992; Miyazawa et al. 1999, 2002; Enami et al. 2011). On one hand, in TBY-2 cells, starch synthesis linked to cell and proplastid differentiation is under the control of exogenous supply of cytokinin (Miyazawa et al. 1999, 2002; Enami et al. 2011). On the other hand, starch synthesis and accumulation also depend on sucrose availability in the culture medium as shown by Kitahara et al. (1998) for Ipomea cell suspension that was able to produce a greater amount of starch in a $7 \%$ sucrose medium than in a $3 \%$ one. Chemically, starch is a large plant polysaccharide composed of chains of glucose residues bound with a glycosidic linkage. Starch could be linear or branched and organized in granules in the stromal compartment of plastids. Amylopectin corresponds to a linear or poorly branched form of starch with glucose linked in $\alpha$-1,4- linkages and amylose is the most branched form with both $\alpha$ 1,4- and $\alpha-1,6$ linkages (Zeeman et al. 2010; Fan and Picchioni. 2020).

According to the amount and structure of both polymers that could be complexed with lipid within granules that present a variety of size and morphology, it is relevant to differentiate and discuss the 
different kinds of starch (Beckles and Thitisaksakul 2014; Vamadevan and Bertoft 2020). For instance, high amylose content leads to smaller granules or amyloplasts (Beckles and Thitisaksakul, 2014). Starch biosynthesis, and to a lesser extent, its catabolism, must be highly regulated by both exogenous factors such as nutriment availability and endogenous factors especially plant growth regulators. Starch biosynthesis greatly depends on three key enzymatic activities such as ADP-glucose pyrophosphorylase (EC 2.7.7.27), starch synthase (EC 2.4.1.21) and Starch Branching enzyme (SBE; EC 2.4.1.18) (Ghosh and Preiss, 1966; Martin and Smith 1995; Buléon et al. 1998; Beckles and Thitisaksakul 2014; Smith and Zeeman 2020).

In our laboratory, TBY-2 cells have been cultivated in medium supplemented with auxin alone and diluted every seven days for several years (Issawi et al. 2017). Surprisingly, we discovered that they acquired the ability to produce starch from middle-exponential to beginning of stationary growth phases without any cytokinin supply as previously described by Miyazawa et al. (1999 and 2002) and Enami et al. (2011). Thus, we decided to explore this new characteristic in terms of starch composition, granule size, and starch synthase activity determination. This is an unexpected feature that allows our TBY-2 line to produce calibrated starch in very short time period and with a minimal cost.

\section{Material and methods}

\section{TBY-2 cell suspension cultures and staining for starch}

Tobacco Bright Yellow-2 cell suspension was subcultured every 7 days, by transferring $1.5-2 \mathrm{~mL}$ aliquot into $40 \mathrm{~mL}$ of fresh medium as described by Issawi et al. (2017). The TBY-2 cell suspension was maintained under dark conditions and continuous agitation $(140 \mathrm{rpm})$ at $22{ }^{\circ} \mathrm{C}$ in modified Murashige and Skoog medium, supplemented with $0.27 \mathrm{mg} . \mathrm{L}^{-1}$ 2,4-dichlorophenoxyacetic acid; $10 \mathrm{mg} . \mathrm{mL}^{-1}$ thiamine-HCl; $100 \mathrm{mg} . \mathrm{L}^{-1}$ myo-inositol; 30 g.L $\mathrm{L}^{-1}$ sucrose and $200 \mathrm{mg} . \mathrm{L}^{-1} \mathrm{KH}_{2} \mathrm{PO}_{4}$, $\mathrm{pH} 5.8$.

Lugol staining was performed as follows: $1 \mathrm{~mL}$ of TBY-2 cells was incubated with $50 \mu \mathrm{L}$ Lugol concentrated solution (commercial solution from Sigma) for $10 \mathrm{~min}$. at room temperature. Pictures were taken with an Olympus photonic microscope.

\section{Extraction of starch granules for Environmental scanning electron microscope (ESEM)} analysis

Starch granules were extracted according to Kitahara et al. (1998), with modifications. Briefly, 500 mg of TBY-2 cells were grounded in liquid nitrogen and homogenized in $10 \mathrm{ml}$ distilled water for 
$3 \mathrm{~min}$. The homogenized cells were centrifuged $\left(4000 \mathrm{rpm}, 10 \mathrm{~min} ., 4^{\circ} \mathrm{C}\right)$. The pellet was washed with cold distilled water, resuspended in $10 \%(\mathrm{v} / \mathrm{v})$ toluene, centrifuged and washed twice with distilled water. The white starch fraction was placed on the top of percoll $(1 \mathrm{ml}$ suspension per 10 $\mathrm{ml}$ percoll) and centrifuged $\left(8000 \mathrm{rpm}, 12 \mathrm{~min} ., 4^{\circ} \mathrm{C}\right)$. The precipitated granule fraction was washed twice with distilled water and lyophilized. Lyophilized granules were observed via Environmental Scanning Electronic Microscope (FEI QUANTA FEG ESEM 450). Mass yield was calculated as a percentage of lyophilized granules fraction per TBY-2 dry weight. Commercial starch from wheat was purchased from Natilec Chamtor (Bazancourt, Fr). Granule sizes were measured from ESEM pictures using ImageJ tools.

\section{Amylose and amylopectin assays}

Assays were performed as described by Jarvis and Walker (1993) and Jiang et al. (2003). Briefly, $300 \mathrm{mg}$ (fresh weight) of cells were ground in liquid nitrogen. Powder was transferred into $2 \mathrm{~mL}$ $\mathrm{KOH}(0.5 \mathrm{M})$ and vigorously vortexed. The mixture was heated for $15 \mathrm{~min}$. at $80^{\circ} \mathrm{C}$ and vortexed every 3 min. $1 \mathrm{~mL} \mathrm{H}_{2} \mathrm{O}$ was added to $1 \mathrm{~mL}$ of the mixture. The $\mathrm{pH}$ was adjusted to 3.5 with $1 \mathrm{M}$ $\mathrm{HCl}$. Then, $200 \mu \mathrm{L}$ of Lugol solution were added and the final volume was adjusted to $10 \mathrm{~mL}$ with $\mathrm{H}_{2} \mathrm{O}$. Absorbances at 656.5 and $461.5 \mathrm{~nm}$ for amylose and 760 and $555 \mathrm{~nm}$ for amylopectin were determined. As standards, $40 \mathrm{mg}$ amylose or amylopectin purchased from Sigma and Fluka Biochemica, respectively, were mixed with $5 \mathrm{~mL} 1 \mathrm{M} \mathrm{KOH}$ and $5 \mathrm{~mL} \mathrm{H}_{2} \mathrm{O}$. After dilutions, 4 standard curves were established that were then used to determine amounts of amylose and amylopectin in samples.

\section{Starch synthase assay}

Cell extracts (up to $200 \mathrm{mg}$ fresh weight) were obtained after grinding in liquid nitrogen and solubilized in extraction buffer: $100 \mathrm{mM}$ tricine- $\mathrm{NaOH} \mathrm{pH} 8,8 \mathrm{mM} \mathrm{MgCl} 2,2 \mathrm{mM}$ EDTA, $50 \mathrm{mM}$ mercaptoethanol, $12.5 \%$ (v/v) glycerol, $5 \%$ (w/v) PVP. After centrifugation (10 000 g, 5 min.), Bradford assay using Bovine Serum Albumin as standard was performed on supernatants. Extracts were kept at $-20^{\circ} \mathrm{C}$ until used.

Starch synthase assay was performed as described by Nakamura et al. (1989), and modified by Lebon et al. (2016). $50 \mu \mathrm{L}$ supernatant were added to $230 \mu \mathrm{L}$ buffer (50 mM HEPES-NaOH pH 7.4, 1.6 mM ADP-glucose, $0.7 \mathrm{mg}$ amylopectin, $15 \mathrm{mM}$ DTT and the mixture was incubated for $20 \mathrm{~min}$., and then for $2 \mathrm{~h}$ at $30^{\circ} \mathrm{C}$. The enzyme was then inactivated by boiling for $30 \mathrm{sec} .280 \mu \mathrm{L}$ of the mixture were mixed to $100 \mu \mathrm{L} 50 \mathrm{mM}$ HEPES-NaOH pH 7.4, 4 mM phosphoenolpyruvate, 
$200 \mathrm{mM} \mathrm{KCl}, 10 \mathrm{mM} \mathrm{MgCl}_{2}$ and 1.2 units of pyruvate kinase. The solution was incubated for 30 min. at $30^{\circ} \mathrm{C}$. ADP produced by starch synthase was converted into ATP; the solution was boiled $30 \mathrm{sec}$. and centrifugated (10 $000 \mathrm{~g}, 5 \mathrm{~min}$.). $300 \mu \mathrm{L}$ supernatant were then mixed with $300 \mu \mathrm{L}$ buffer $50 \mathrm{mM}$ HEPES-NaOH (pH 7.4), $10 \mathrm{mM}$ glucose, $20 \mathrm{mM} \mathrm{MgCl}_{2}, 2 \mathrm{mM}$ NADP, $1 \mu \mathrm{l}$ hexokinase (1.4 units) and $1 \mu \mathrm{L}$ glucose-6-phosphate dehydrogenase ( 0.35 units). Hexokinase from Saccharomyces cerevisiae (H6380), glucose-6-phosphate dehydrogenase from Leuconostoc mesenteroide (G5885) and pyruvate kinase from rabbit muscle (P9136) were purchased from Sigma-Aldrich. Starch synthase activity was calculated by monitoring increase in NADPH absorbance at $340 \mathrm{~nm}$ with molar extinction coefficient $6.22 \mathrm{mM} . \mathrm{cm}^{-1}$.

\section{Statistical analysis}

All biological experiments were performed at least three times independently. Results were expressed as mean $\pm \mathrm{SD}$ (Standard Deviation). Data were analyzed by one-way ANOVA using the PAST free software.

\section{Results}

Starch granules in TBY-2 cells from four, seven, nine and ten days after dilution were visualized using Lugol staining under a photonic microscope (Fig. 1). The nucleus' position in the cytoplasm was visible as a dark ovoid shape. Starch granules were detected as numerous and very small granules of approximately $1.4 \mu \mathrm{m}$ in diameter (Fig. 1). When observed under environmental SEM, D10 starch granules were obviously smaller than heterogeneous and larger granules from commercial starch sample meaning that the new TBY-2 line should be able to produce a starch with richer amylose content as shown in Ipomea cell suspension (Fig. 1). Indeed, very small starch spherical granules (1-3 $\mu \mathrm{m})$ were also observed in Ipomea cordatotriloba cell suspension cultivated on $3 \%$ sucrose and $2.4 \mathrm{D}$ (Kitahara et al. 1998).

We assayed the amylose and amylopectin contents in TBY-2 cells following their growth curve. Experimental determinations of both contents led to an estimation of starch content and calculation of the ratio of amylopectin to amylose in cells reported in Table 1. A constant amount of starch was calculated for cells isolated from D2 to D7 $\left(\sim 5 \mathrm{mg} . \mathrm{g}^{-1} \mathrm{FW}\right)$. A significant increase in starch content $\left(\sim 2.5 \mathrm{mg} . \mathrm{g}^{-1} \mathrm{FW}\right)$ was measured at D8 and D9 which corresponds to the beginning of the stationary phase (Table 1). When a cell suspension was taken at the end of the stationary phase (D12), the starch content decreased to $\sim 4.7 \mathrm{mg} . \mathrm{g}^{-1} \mathrm{FW}$, which was likely linked to sucrose depletion in the spent medium (Table 1). Nevertheless, the ratio of amylopectin /amylose was 
nearly unchanged between 1.4 to 1.8 with the exception of D9 where its value was 2.7 (Table 1). Thus, we deduced that TBY-2 cells were essentially able to synthesize a starch consisting mainly of amylose, apart from the D9 cells, that produced a starch enriched in amylopectin. In fact, the starch composition determined in D9 cells corresponded to a classical composition in plants (from 15 to $30 \%$ amylose $)$, with a significant percentage of starch (9.22 $\pm 0.68 \%$, Table 2$)$. Furthermore, amylose and amylopectin assays showed that the TBY-2 line produced a starch with an amylopectin to amylose ratio around 1.5 , which leads to a more resistant starch.

According to our amylose and amylopectin assays, we should observe an increase in starch synthase activity between D7 and D8. As reported in Table 1, starch synthase activity was perfectly correlated to the starch accumulation with a peak of enzymatic activity just before starch accumulation in D9 cells.

\section{Discussion}

TBY-2 cells' new characteristic was due to an intense and rapid cell division over years of culture. Divisions induce mutations that must not be bypassed leading to inevitable somaclonal variation(s) (Larkin et al. 1981). It is quite difficult to detect and characterize them even by using powerful molecular tools (Bairu et al. 2011). In our case, we presumed that the new starch accumulation phenotype, was constitutively expressed with or without auxin. Several regulatory and/or metabolic pathways could be altered such as auxin signaling and/or retrograde regulation by proplastids (Enami et al. 2011). Mutations could take place in both nuclear and plastidial genomes that are interdependent in many metabolism regulatory pathways. Our fast-growing cell line that only needs auxin to proliferate, constitutively synthesized starch although other TBY-2 lines only did it under auxin deprivation or cytokinin addition (Miyazawa et al. 1999, 2002; Enami et al. 2011).

This means that TBY-2 cells still conserve the possibility to synthesize starch under some specific conditions. TBY-2 cells still have the molecular machinery such as enzymes and regulators that are involved in the synthesis of starch and are normally repressed by controlling the presence of auxin. Thus, as in our TBY-2 cell line, cells did not depend anymore on the auxin depletion to synthesize starch as shown by Miyazawa et al. 1999, we hypothesized that the mutation(s) could be linked to auxin signalization pathway alterations. Moreover, Sakai et al. (1996) proposed that starch accumulation was controlled by hormonal conditions rather than by cell division arrest. Sugar and auxin are together key players to regulate cell growth and division in cell suspension 
cultures and plants (Riou-Khamlichi et al. 2000; Sairanen et al. 2012; Wang and Yong-Ling 2013).

Nevertheless, it was shown that water-soluble sugars also regulate auxin biosynthesis through Phytochrome-Interacting (Pif) Factor proteins (Wang et al. 2013). Consequently, to understand the starch accumulation in treated cells independently to auxin, proteins involved in auxin signaling linked to sugar availability should be further investigated.

TBY-2 cells were able to accumulate a large amount of starch at the beginning of stationary growth phase that was strongly correlated with an increase in starch synthase activity. Furthermore, this cell line produced an amylopectin-rich starch with a ratio amylopectin over amylose of 2.7 which also linked to typical small granules (size around $1.4 \mu \mathrm{m}$ ).

From 2004 to 2019, the EU increased its starch and derivative production from 8.7 million tons to 10.7 million tons (Yazid et al. 2018; Starch Europe, 2021). In this context, this cell line could be seen as a novel source of starch production at low cost. We are confident that it could be of interest for the food and industry but also in the health domain as a prebiotic and/or dietary fiber.

Author contribution statement VA., MI and C.R. designed and performed the experiments. They wrote and finally approved the manuscript.

\section{Acknowledgements}

Mohammad Issawi was granted by a post-doctoral fellowship from University of Limoges and Veronica Ambrosini was supported by a Grant from the region of Nouvelle Aquitaine.

\section{References}

Bairu, M.W., Aremu, A.O., and Staden, J.V. 2011. Somaclonal variation in plants: causes and detection methods. Plant Growth Regul. 63: 147-173. doi:10.1007/s10725-010-9554-x.

Beckles, D.M., and Thitisaksakul, M.C. 2014. Use of Biotechnology to engineer starch in cereals. Encyclopedia of Biotechnology in Agriculture and Food. 1-8. doi:10.1081/E-EBAF120051354.

Buléon, A., Colonna, P., Planchot, V., and Ball, S. 1988. Starch granules: structure and biosynthesis. Int. J. Biol. Macromol. 16: 85-112. doi:10.1016/S0141-8130(98)00040-3.

Coenen, C., and Lomax, T.L. 1997. Auxin-cytokinin interactions in higher plants: old problems and new tools. Trends Plant Sci. 2: 351-356. doi:10.1016/S1360-1385(97)84623-7. 
De Pinto, M.C., Locato, V., Sgobba, A., Romero-Puertas, MdC., Gadaleta, C., Delledonne, M., and De Gara, L. 2013. S-nitrosylation of ascorbate peroxidase is part of programmed cell death signaling in tobacco bright yellow-2 cells. Plant Physiol. 163: 1766-1775. doi:10.1104/pp.113.222703.

Enami, K., Ozawa, T., Motohashi, N., Nakamura, M., Tanaka, K., and Hanaoka, M. 2011. Plastidto-nucleus retrograde signals are essential for the expression of nuclear starch biosynthesis genes during amyloplast differentiation in Tobacco BY-2 cultured cells. Plant Physiol. 157: 518-530. doi:10.1104/pp.111.178897.

Fan, Y., and Picchioni, F. 2020. Modification of starch: A review on the application of "green" solvents and controlled functionalization. Carbohydr. Polym. 241: 116350. doi:10.1016/j.carbpol.2020.116350.

Ghosh, H.P., and Preiss, J. 1966. Adenosine diphosphate glucose pyrophosphorylase. A regulatory enzyme in the biosynthesis of starch in spinach leaf chloroplasts. J. Biol. Chem. 241: 44914504.

Hurný, A., and Benková, E. 2017. Methodological Advances in Auxin and Cytokinin Biology. Methods Mol. Biol. 1569: 1-29. doi:10.1007/978-1-4939-6831-2_1.

Issawi, M., Muhieddine, M., Girard, C., Sol, V., and Riou, C. 2017. Unexpected features of exponentially growing Tobacco Bright Yellow-2 cell suspension culture in relation to excreted extracellular polysaccharides and cell wall composition. Glycoconj. J. 34: 585-590. doi:10.1007/s10719-017-9782-7

Jameson, P.E., and Song, J. 2016. Cytokinin: a key driver of seed yield. J. Exp. Bot. 67: 593-606. doi:10.1093/jxb/erv461.

Jarvis, C.E., and Walker, J.R.L. 1993. Simultaneous, rapid, spectrophotometric determination of total starch, amylose and amylopectin. J. Sci. Food Agric. 63: 53-57. doi: 10.1093/jxb/erv461. Jiang, D., Cao, W., Dai, T., and Jing, Q. 2003. Activities of key enzymes for starch synthesis in relation to growth of superior and inferior grains on winter wheat (Triticum aestivum L.) spike. Plant Growth Regul. 41: 247-257. doi:10.1023/B: GROW.0000007500.90240.7d

Kato, K., Matsumoto, T., Koiwai, S., Mizusaki, S., Nishida, K., Nogushi, M., and Tamaki, E. 1972. Liquid suspension culture of tobacco cells in Fermentation Technology Today. Society of Fermentation Technology, Osaka. Ed G. Terui, pp 689-695 
Kitahara, K., Imamura, K., Omae, Y., and Suganuma, T. 1998. Characterization of molecular structure of starch granules in suspension-cultured cells from Ipomea cordatotriloba Denn. Biosci. Biotechnol. Biochem. 62: 1962-1967. doi:10.1271/bbb.62.1962.

Kobayashi, I., and Hakuno, H. 2003. Actin-related defense mechanism to reject penetration attempt by a non-pathogen is maintained in tobacco BY-2 cells. Planta. 217: 340-345. doi:10.1007/s00425-003-1042-3.

Larkin, P.J., and Scowcroft, W.R. 1981. Somaclonal variation - a novel source of variability from cell cultures for plant improvement. Theor. Appl. Genet. 60: 197-214. doi:10.1007/BF02342540.

Larkin, R.M. 2016. Tetrapyrrole signaling in plants. Front. Plant Sci. 7: 1586-1603. doi:10.3389/fpls.2016.01586.

Laureys, F., Dewitte, W., Witters, E., Van Montagu, M., Inzé D., and Van Onckelen, H. 1988. Zeatin is indispensable for the G2-M transition in tobacco BY-2 cells. FEBS Letters. 426: 2932. doi:10.1016/s0014-5793(98)00297-x.

Lebon, G., Rondeau, M., Sanchez, L., Barka, E.A., Vaillant-Gaveau, N., Clément, C., and Jacquard, C. 2017. Modulation of the activity of enzymes involved in carbohydrate metabolism during flower development of grapevine (Vitis Vinifera L.). Plant J. 1: 10-17. doi:10.17352/ojps.000003.

Martin, C., and Smith, A.M. 1995. Starch biosynthesis. The Plant Cell. 7: 971-985. doi:10.1105/tpc.7.7.971.

Miller, C.O., Skoog, F., Von Saltza, M.H., and Strong, F.M. 1955. Kinetin, a cell division factor from deoxyribonucleic acid. J. Am. Chem. Soc. 77: 1392-1392. doi:10.1021/ja01610a105.

Miyazawa, Y., Sakai, A., Miyagishima, S., Takano, H., Kawano, S., and Kuroiwa, T. 1999. Auxin and cytokinin have opposite effects on amyloplast development and the expression of starch synthesis genes in cultured Bright Yellow-2 Tobacco cells. Plant Physiol. 121: 461-470. doi:10.1104/pp.121.2.461.

Miyazawa, Y., Kato, H., Muranaka, T., and Yoshida, S. 2002. Amyloplast formation in cultured tobacco BY-2 cells requires a high cytokinin content. Plant Cell Physiol. 43: 1534-1541. doi:10.1093/pcp/pcf173.

Moscatiello, R., Baldan, B., and Navazio, L. 2013. Plant cell suspension cultures. Methods Mol. Biol. 903: 77-93. doi:10.1007/978-1-62703-152-3_5. 
Murashige, T., and Skoog, F. 1962. A revised medium for rapid growth and bioassays with tobacco tissue cultures. Physiol Plant. 15: 473-497. doi:10.1111/j.1399-3054. 1962.tb08052.x.

Nagata, T., Nemoto, Y., and Hasezawa, S. 1992. Tobacco BY-2 Cell Line as the « HeLa » Cell in the Cell Biology of Higher Plants. Int. Rev. Cytol. 132: 1-30. doi:10.1016/S00747696(08)62452-3.

Nakamura, Y., Yuki, K., Park, S.Y., and Ohya, T. 1989. Carbohydrate metabolism in the developing endosperm of rice grains. Plant Cell Physiol. 30: 833-839. doi: 10.1093/oxfordjournals.pcp.a077813

Riou-Khamlichi, C., Huntley R., Jacqmard, A., and Murray, J.A.H. 1999. Cytokinin activation of Arabidopsis cell division through a D-type cyclin. Science. 283: 1541-1544. doi:10.1126/science.283.5407.1541.

Riou-Khamlichi, C., Menges, M., Healy, J.M.S., and Murray, J.A.H. 2000. Sugar control of the plant cell cycle: differential regulation of Arabidopsis D-type cyclin gene expression. Mol. Cell. Biol. 20: 4513-4521. doi:10.1128/mcb.20.13.4513-4521.2000.

Riou, C., Calliste, A., Da Silva, A., Guillaumot, D., Rezazgui, O., Sol, V., and Leroy-Lhez, S. 2014. Anionic porphyrin as a new powerful cell death inducer of Tobacco Bright Yellow-2 cells. Photochem. Photobiol. Sci. 13: 621-625. doi:10.1039/C3PP50315A.

Sairanen, I., Novák, O., Pěnčík, A., Ikeda, Y., Jones, B., Sandberg, G., and Ljung, K. 2012. Soluble carbohydrates regulate auxin biosynthesis via PIF proteins in Arabidopsis. The Plant Cell. 24: 4907-4916. doi:10.1105/tpc.112.104794.

Sakai, A., Kawano, S., and Kuroiwa, T. 1992. Conversion of proplastids to amyloplasts in Tobacco Cultured Cells is accompanied by changes in the transcriptional activities of plastid genes. Plant Physiol. 100: 1062-1066. doi:10.1104/pp.100.2.1062.

Sakai, A., Yashiro, K., Kawano, S., and Kuroiwa, T. 1996. Amyloplast formation in cultured tobacco cells; effect of plant hormones on multiplication, size and starch content. Plant Cell Rep. 15: 601-605. doi:10.1007/BF00232461

Smith, A.M. and Zeeman, S.C. 2020. Starch: a flexible, adaptable carbon store coupled to plant growth. Ann. Rev. Plant Biol. 71: 1-29. doi:10.1146/annurev-arplant-050718-100241

Srba, M., Černíková, A., Opatrný, Z., and Fischer, L. 2016. Practical guidelines for the characterization of tobacco BY-2 cell lines. Biol. Plant. 60: 13-24. doi:10.1007/s10535-0150573-3. 
Starch Europe. 2021. From https://starch.eu/. Accessed on 19 ${ }^{\text {th }}$ of April 2021.

Takahashi, S., Kojo, K.H., Kutsuna, N., Endo, M., Toki, S., Isoda, H., and Hasezawa, S. 2015. Differential responses to high- and low-dose ultraviolet-B stress in Tobacco Bright Yellow-2 cells. Front. Plant Sci. 6: 254-264. doi:10.3389/fpls.2015.00254.

Vamadevan, V., and Bertoft E. 2020. Observations on the impact of amylopectin and amylose structure on the swelling of starch granules. Food Hydrocoll. 103: 105663 doi: 10.1016/j.foodhyd.2020.105663.

Wang, L., and Ruan, Y.L. 2013. Regulation of cell division and expansion by sugar and auxin signaling. Front. Plant Sci. 4: 1-10. doi:10.3389/fpls.2013.00163.

Yazid, N.S.M., Abdullah, N., Muhammad, N., and Matias-Peralta H. M. 2018. Application of Starch and Starch-Based Products in Food Industry. J. Sci. Techn. 10: 144-174. doi:10.30880/jst.2018.10.02.023

Zeeman, S.C., Kossmann, J. and Smith, A.M. 2010. Starch: its metabolism, evolution, and biotechnological modification in plants. Annu. Rev. Plant Biol. 61: 209-234. doi:10.1146/annurevarplant-042809-112301.

0

1

23

24

25

26

Table 1: Amylose and amylopectin quantification starch estimation and starch synthase determination in TBY-2 cells at different times of growth curve. Ratio [amylopectin/amylose] was determined from experimental quantifications of amylose and amylopectin. FW: fresh weight; nd: not determined. Results are the mean of 3 to 5 biological independent experiments \pm SD. Statistical analysis was performed referring to D7; $p$ value was reported in italic under each assay. No p value under assays mean that statistical test was not significant. nd: not determined. 


\begin{tabular}{|c|c|c|c|c|c|c|c|}
\hline & \multicolumn{7}{|c|}{ Days after dilution } \\
\hline & 2 & 4 & 7 & 8 & 9 & 10 & 12 \\
\hline $\begin{array}{l}\text { Amylose content } \\
\left(\mathrm{mg.g}{ }^{-1} \text { FW) }\right.\end{array}$ & $2.15 \pm 0.13$ & $\begin{array}{c}2.42 \\
\pm 0.33 \\
\end{array}$ & $1.88 \pm 0.1$ & $\begin{array}{c}2.85 \\
\pm 0.07 \\
\end{array}$ & $\begin{array}{c}2.31 \\
\pm 0.18 \\
\end{array}$ & $\begin{array}{c}3.05 \\
\pm 0.63 \\
\end{array}$ & $\begin{array}{c}1.92 \\
\pm 0.27 \\
\end{array}$ \\
\hline $\begin{array}{l}\text { Amylopectin } \\
\text { Content } \\
\left(\mathrm{mg} \cdot \mathrm{g}^{-1} \mathrm{FW}\right)\end{array}$ & $3.19 \pm 0.24$ & $3.54 \pm 0.48$ & $3.24 \pm 0.15$ & $5.05 \pm 0.38$ & $6.3 \pm 0.5$ & $3.74 \pm 0.71$ & $2.8 \pm 0.36$ \\
\hline $\begin{array}{l}\text { Amylopectin/amylose } \\
\text { ratio }\end{array}$ & 1.48 & 1.46 & 1.72 & 1.77 & 2.72 & 1.22 & 1.46 \\
\hline $\begin{array}{l}\text { Total starch content } \\
\left(\mathrm{mg.g}^{-1} \text { FW) }\right.\end{array}$ & $5.34 \pm 0.38$ & $5.79 \pm 0.62$ & $5.12 \pm 0.23$ & $\begin{array}{c}7.9 \pm 0.32 \\
4.910^{-4}\end{array}$ & $\begin{array}{l}8.65 \pm 0.4 \\
4.110^{-4}\end{array}$ & $\begin{array}{l}6.79 \pm 0.58 \\
3.710^{-3}\end{array}$ & $4.73 \pm 0.39$ \\
\hline $\begin{array}{l}\text { Starch synthase } \\
\text { (nmol NADPH. } \text { mg-1 }^{-1} \\
\text { proteins. } \text { min }^{-1} \text { ) }\end{array}$ & $0.28 \pm 0.045$ & $0.25 \pm 0.35$ & $4.65 \pm 0.59$ & $\begin{array}{c}8.23 \pm 0,49 \\
1.5710^{-2}\end{array}$ & $\begin{array}{l}2.8 \pm 0,1 \\
6.5610^{-3}\end{array}$ & nd & $\begin{array}{c}0.89 \pm 0.36 \\
1.810^{-4}\end{array}$ \\
\hline
\end{tabular}

Table 2: Determination of starch mass yield in TBY-2 cells in the beginning of stationary phases (D9 and D10). Results are the mean of three independent experiments.

\begin{tabular}{|l|l|l|l|}
\hline & Dry weight $\mathbf{( m g )}$ & $\begin{array}{l}\text { Yield of the starch } \\
\text { granules }(\mathbf{m g})\end{array}$ & $\begin{array}{l}\text { Starch mass yield } \\
\mathbf{( \% )}\end{array}$ \\
\hline D9 cells & $28.1 \pm 1.6$ & $2.58 \pm 0.06$ & $9.22 \pm 0.68$ \\
\hline D10 cells & $31 \pm 1$ & $1.6 \pm 0.12$ & $5.1 \pm 0.48$ \\
\hline
\end{tabular}

Fig. 1: Starch granules in TBY-2 cells or isolated. TBY-2 cells were observed at 4, 7, 9 and 10 days after dilution and stained with Lugol solution. Arrows indicated starch granules. Lower panel corresponds to starch granules isolated from 9 and 10-day-old TBY-2 cells observed under SEM compared to commercial starch granules. Granule sizes, measured by ImageJ tools, are $1.36 \mu \mathrm{m} \pm$ 0.4 for D9 and $1.45 \mu \mathrm{m} \pm 0.39$ for D10, respectively. D: day after dilution. Scale bar $=10$ or 20 $\mu \mathrm{m}$. Stars indicate nuclei. 


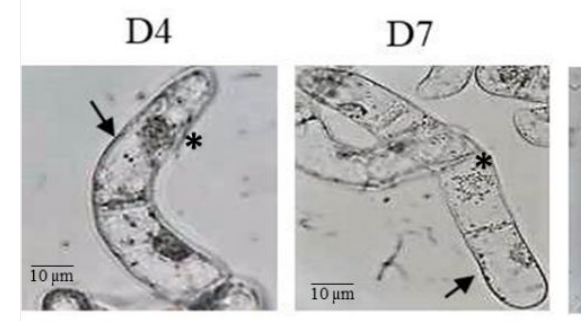

D9
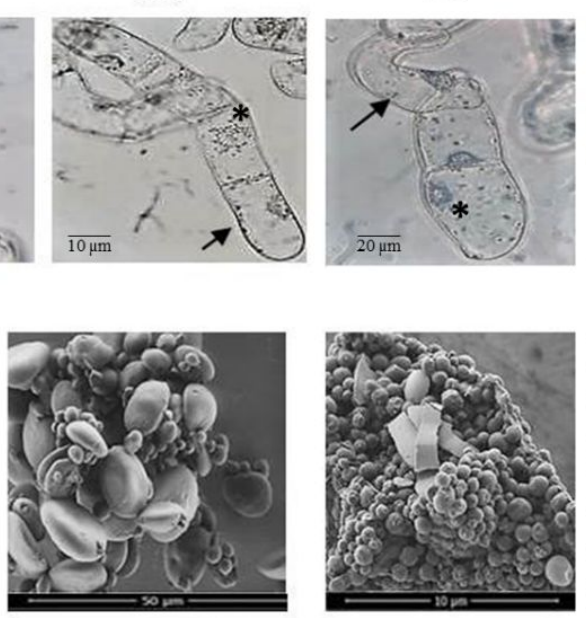

Commercial Starch

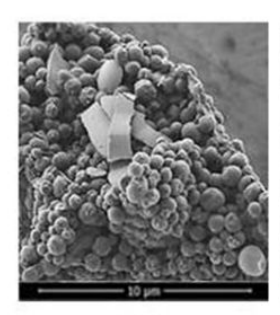

D9
D10
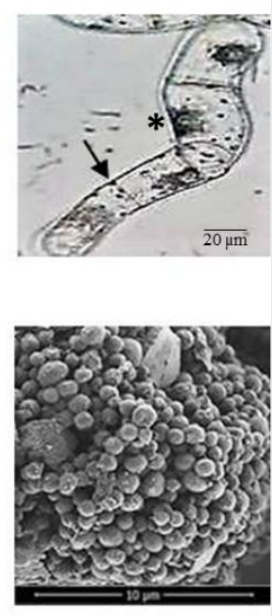

D10 